\title{
Harmonization of International Law in Indonesian Legal System: The Study of Indonesian Migrant Workers Protection Overseas $^{1}$
}

\author{
Achmad Zulfikar ${ }^{12}$, Satria Sukananda ${ }^{3}$, Hamza Baharuddin ${ }^{4}$, Said Sampara ${ }^{4}$ \\ ${ }^{1}$ Association of Indonesian Bachelor in International Relations (AIBIRs/PaSHII) \\ ${ }^{2}$ Department of International Relations Universitas Fajar, Makassar \\ ${ }^{3}$ Regional Office of Kepulauan Riau, Ministry of Agrarian Affairs and Spatial Planning/ \\ National Land Agency, Republic of Indonesia \\ ${ }^{4}$ Faculty of Law Universitas Muslim Indonesia, Makassar \\ Corresponding author: apa@kabarfikar.com
}

\begin{abstract}
This study aims to describe and analyze the development of the harmonization of international conventions of migrant workers rights with the Indonesian Migrant Workers Act and to examine the process of adopting the substance of international conventions on the protection of migrant workers' rights into the Indonesian Migrant Workers Act. This study useslegalnormative research methodby reviewing principles, concepts of law and related legislations and regulations. The results of this study shows that: harmonization of international conventions on the protection of migrant workers' rights into Law No. 18 of 2017 is carried out through a transformation that refers to the position of international conventions in Indonesian national law; and the substance of international conventions to protect the rights of migrant workers is adopted through two processes which are a political process of discussion of Amendment of Law No. 39 of 2004 to become Law No. 18 of 2017 by the House of Representatives of Republic of Indonesia and civil society organizations and a legal processof referring Law No. 6 of 2012 in Amendment to Law No. 39 of 2004 to become Law No. 18 of 2017 version of May 2016 and identifying seven findings to compare the Law No. 18 of 2017 and the ratification law of the Convention.
\end{abstract}

Keywords: Harmonization, International Law, Indonesian Legal System, Indonesian Migrant Workers

\section{Introduction}

In the global context, the right to work is the concept that people have a human right to work or engage in productive employment, and may not be prevented from doing so. The right to work is enshrined in the Universal Declaration of Human Rights and recognized in international human rights law through its inclusion in the International Convenant on Economic, Social and Cultural Rights, where the right to work emphasizes economic, social and cultural

\footnotetext{
${ }^{1}$ This articles already approved for publication in Jurnal Hubungan Luar Negeri (Journal of Indonesian Foreign Affairs) published by M inistry of Foreign Affairs, Republic of Indonesia. This articles is pre-print published to invite public comments. If you have any opinion regarding this articles, please send to corresponding author email as stated above.
} 
development. Meanwhile in Indonesia, Indonesian constitution guarantees the right of every Indonesian citizen (WNI) to get a job and freedom to choose jobs protected under Indonesian Constitution of 1945 as stipulated in the Article 27 Paragraph 2: "every citizen has the right to a decent livelihood for humanity". Furthermore, this right is regulated in Law No. 13 of Year 2003 regarding Employment.

However, the implementation of right to work has not been able to be optimally fulfilled domestically, due to the low absorption of employment. Thus, migrating abroad becomes one of the alternatives for Indonesian citizens for seeking employment. Indonesian Migrant Workers, such is the name for Indonesian citizens who work overseas which were known as Indonesian Workforce (TKI). These people expect to have larger income and better living conditions in their country where they employed. And responding to high interest in working overseas, Indonesian government issued Law No. 39 of Year 2004 regarding Placement and Protection of Indonesian Workers Overseas. This Law is expected to provide optimal protection in their country of placement.

In addition to issuing regulations at the domestic level, diplomatic efforts to protect Indonesian workers abroad are also carried out by signing international laws in form of conventions such as the International Convention on the Protection of the Rights of All Migrant Workers and Members of their Families on September 22, 2004 by the Foreign Minister Hassan Wirajuda in New York, US, conducted on the occasion of annual UN agreement at the $59^{\text {th }}$ UN Assembly Session. However, the Convention had 8 years (September 22, 2004-2 May 2012) before it can be adopted into the Indonesian legal system in the form of Law No. 6 of Year 2012 regarding the ratification of the International Convention on the Protection of the Rights of All Migrant Workers and Members of their Families. After the ratification of the International Convention, the Indonesian government gained momentum to increase bargaining position towards employment targets by harmonizing the Indonesian legal system with international law in the form of legal harmonization.

Globally, countries all over the world have been paying attention to the protection of migrant workers' rights. This is indicated by convening the 2016 United Nations Summit for Refugees and Migrants which was attended by 193 United Nations member countries on September 19, 2016. This meeting resulted in the New York Declaration for Refugees and Migrants. Section III of the Commitments for Migrants article 48 states that: "we call upon States that have not done so to consider ratifying, or acceding to, the International Convention on the Protection of the Rights of All Migrant Workers and Members of Their Families. We call also on States that have not done so to consider acceding to relevant International Labour Organization conventions, as appropriate. We note, in addition, that migrants enjoy rights and protection under various provisions of international law"

The commitment above shows that International Convention on the Protection of the Rights has become an instrument recommended by the United Nations as an effort to provide protection to migrant workers anywhere.

Several studies on legal harmonization have been published by Akbar Kurnia Putra (2014) and Mosgan Situmorang (2014). Putra (2014) in his research concluded that all actions recommended in the European Convention on Cyber Crime (ECCC) are regulated in the 
Electronic Information and Transaction Act. In addition, Situmorang (2014) in his research concluded that the United Nations Convention Against Corruption needs to be harmonized with the regulation on eradicating corruption in Indonesian national law namely Law No. 39 of 1999, Law No. 20 of 2001 and in the Criminal Code (KUHP). This explanation is in line with the opinion of Zainal Arifin Muhtar and Edi O.S. Hiariej in a national seminar on realizing law enforcement and the implementation of corruption crime courtsin a civil and just manner (2018).

Meanwhile, studies of international conventions on the protection of migrant workers' rights have been published by Ardiani (2009), Zulfikar (2014) and Zulfikar (2015). Ardiani (2009) in his research showed the dynamics that occurred before the International Convention on the Protection of the Rights of All Migrant Workers was ratified. Furthermore, Zulfikar (2014) examines the implications of ratifying international conventions on the protection of migrant workers' rights in Indonesian national law, but has not yet carried out specific studies related to harmonization. Then, Zulfikar (2015) concluded in his research that the rationality of the Indonesian government in ratifying international conventions to protect the rights of migrant workers is based on economic and political rationale.

The novelty value of this paper is to expand the knowledge of labor diplomacy efforts by showing the convergence of Indonesia's national interests through the protection of overseas Indonesian workers as mandated by the Constitution with a global campaign to increase sensitivity to the protection of migrant workers through the New York Declaration for Refugees and Migrants. Harmonization between international law and the Indonesian legal system might create a bridge to make Indonesian jurisdiction which limited to its territorial borders able to reach its citizens who work abroad. Thus the purpose of this paper is to analyze the status of international law in the Indonesian legal system, and then analyze the process of harmonization and adoption of international conventions to protect the rights of migrant workers in Law No. 18 of 2017 concerning the Protection of Indonesian Migrant Workers.

\section{Method}

This research is a normative legal research using literature studies, which is a legal research that puts law as a building system of norms. (Fajar \& Achmad, 2010: 34) The search for materials is based on existing legal materials in the form of legislation as well as written works such as books or other articles contained on sites that are relevant to the object of this research. This method is used to understand the harmonization of international law in indonesian legal system: the study of indonesian migrant workers protection overseas.

The approach to this research is the legislation (statue) approach. The approach is carried out by reviewing various legislation or jurisprudence related to the legal issues in examination.

The legal and non-legal material obtained in this study will be analyzed prescriptively using deductive method. It meansthat general data, legal principles, doctrine, and legislation are systematically arranged as a set of legal facts to examine harmonization of international law in Indonesian legal system: the study of Indonesian migrant workers protection overseas.

\section{Discussion}




\section{A. Status of International Law in Indonesian Legal System}

The place of International law in Indonesian national law is a noteworthy matter in harmonizing international agreements (Law No. 6 of 2012) into Indonesian national law (Law No. 18 of 2017). To understand this, it is important to examine the two major schools of thought formed due to the different views from the scholars regarding the binding basis of international law. According to Damos Dumoli Agusman, the two major schools are:

(a) Dualism school that places international law as a legal system separate from national law. In this case there is no hierarchical relationship between these two legal systems. The consequence of this school of thought is the need for a "transformation" legal institution to convert international law into national law based on the laws and regulations that apply to the conversion procedure. The binding of a country to an agreement (e.g. through ratification) must be continued by a transformation process through the making of national legislation. By converting this international legal code into national law, the codes will change its character into a product of national law and apply as a national law and subject to the order of national legislation. Because a separate system does not allow for conflicts between these two laws;

(b) Monism school which places international law and national law as part of a unified legal system. International law are in effect within the scope of national law without having to go through a transformation process. The binding of a country to an agreement (e.g. by ratification) constitutes the incorporation of the agreement into national law and does not require the same national legislation to enforce it in national law. Even if there are national legislation that regulates the same problem, the legislation in question is only an implementation of the intended international law. In this case, international law that were applied in the national legal system will remain in its character as international law. Given that it is a unified system, there is a possibility of a conflict between national law and international law. For this reason, the school of thought is divided into two, those which prioritize national law (national law primat) and which prioritize international law (international law primat). (Agusman, 2010: 97)

Table 1. Comparison between Monism and Dualism

\begin{tabular}{ll}
\hline \multicolumn{1}{c}{ Monism } & \multicolumn{1}{c}{ Dualism } \\
\hline - International law and national law are & - International law and national law \\
a unified system. & each apply to different domain. \\
- Law enforcers apply international & - Law enforcers apply international law \\
legal norms in their status as norms of & in their status as national legal norms. \\
international law. & \\
- International law is incorporated into & -International law is transformed into \\
national law. & national law. \\
- Possibly emergingconflicts between & - Conflict is not possible due to different \\
international law and national law. & domains. \\
Gave birth to primat international law or & \\
primat national law. & \\
\hline Source: Agusman, (2010), Hukum Perjanjian Internasional: Kajian Teori dan Praktik \\
Indonesia, Bandung: Refika Aditama. pp. 97-98.
\end{tabular}


Furthermore, Soemaryo in Eddy Pratomo explained the two major schools by adding some theories adopted in the relationship between international law and national law, namely:

(a) Monism Theory: This theory views international obligations and state rules are two aspects of the same phenomenon, both originated from a basic norm and rooted from the unified order of legal conceptions. Followersof this theory argue that legal science is a unified field of science. Therefore, international law is a form of law in its truest sense. This theory of monism was pioneered by Wright, Kelsen, Lauterpacht and Duguit;

(b) Dualism Theory: This theory assumes that the rules in the international legal system and national law are distinguished from one another, meaning eachcannot influence or exclude others. International law and national law are both essentially different because each system regulates different problems. Scholars in this theory assume that international law and national law are two different laws because national law is different from international rules and regulations. Followers of this theory are Strupp, Triepel, Hegel and Anzilotti;

(c) Specific Adoption Theory. This theory sees that international law can be applied in the national legal field of a state only if national law permits it or ratifies it specifically as with international agreements;

(d) Transformation Theory. In this theory both international law and national law are two different legal systems, which work separately and therefore, before any international rule or principle can influence national jurisdiction, it must be transformed clearly and specifically into national legislation, by using a proper constitutional mechanism such as the process of ratification or access by the House of Representatives (DPR);

(e) Delegation Theory. This theory argues that the rules of international law in the Constitution of a certain country allow it to stipulate that international agreements can be applied in the field of national law. As such, there is no need for either specific authorization or transformation of the rules of international law in each case. Rules of international law can be applied in the field of national law in accordance with the procedures and systems that exist in each country according to the Constitution;

(f) Inkorporasi Theory. This theory assumes that international law is automatically part of national law without requiring a ratification procedure from the parliament. This theory actually refers to international customary law and the different rules that are applied to international agreements. (Pratomo, 2016: 488-490)

The emergence of several theories shows how important the role and function of international law, including international agreements in the association of nations. The differences (tug-of-war) occurring in the introduction of several theories by international law experts has also indicated a long debate about the dynamic and interactive relationship between international law and national law which in turn requires a firm attitude from the governments of each country. (Pratomo, 2016: 490-491)

Eddy Pratomo described the comparison of concepts between monism (both national law primat and primat international law) with dualism in the following table.

Table 2. Comparison of Monism - Dualism Concepts

\begin{tabular}{|l|l|l|l|}
\hline & $\begin{array}{l}\text { Primat national law } \\
\text { Monism }\end{array}$ & $\begin{array}{l}\text { Primat international law } \\
\text { Monism }\end{array}$ & Dualism \\
\hline
\end{tabular}




\begin{tabular}{|c|c|c|c|}
\hline $\begin{array}{l}\text { Legal } \\
\text { expert }\end{array}$ & $\begin{array}{l}\text { J. J. Moser, C. Bergbohm, } \\
\text { A. Zorn, M. Wensel }\end{array}$ & $\begin{array}{l}\text { W. Kaufmann, Hans } \\
\text { Kelsen, A. Verdross, G. } \\
\text { Scelle }\end{array}$ & H. Triepel, D. Anzilotti \\
\hline & $\begin{array}{l}\text { National law is more } \\
\text { important than } \\
\text { international law because } \\
\text { international law is not a } \\
\text { form of individual behavior } \\
\text { guidelines. } \\
\text { What is prioritized is the } \\
\text { interests of the state } \\
\text { concerned, where this } \\
\text { overrides the existence of } \\
\text { international law as an } \\
\text { independent and separate } \\
\text { body. } \\
\text { Thus this doctrine actually } \\
\text { only recognizes one legal } \\
\text { system, that is, the } \\
\text { national legal system. }\end{array}$ & $\begin{array}{l}\text { This theory stated that } \\
\text { there is a unitary legal } \\
\text { system, where } \\
\text { international law is at the } \\
\text { highest level. } \\
\text { As a result, national law } \\
\text { must always conform and } \\
\text { follow international law. } \\
\text { This is due to the reason } \\
\text { that the subject of } \\
\text { international law is actually } \\
\text { not too different from the } \\
\text { subject of national law, } \\
\text { where in international law } \\
\text { and national law, } \\
\text { individuals are the main } \\
\text { legal subject, even though } \\
\text { in international law the } \\
\text { individual refers to his } \\
\text { status as a state official. }\end{array}$ & $\begin{array}{l}\text { International law and } \\
\text { national law are two } \\
\text { different legal systems } \\
\text { that are separate from } \\
\text { each other. } \\
\text { Differences in content } \\
\text { can be found at: } \\
\text { 1. The subject of the } \\
\text { law (individual for } \\
\text { national and state law } \\
\text { in general for } \\
\text { international law) } \\
2 \text {.Its legal source } \\
\text { (formed by parliament } \\
\text { or jurisprudence as the } \\
\text { main legal source for } \\
\text { national law and } \\
\text { international treaties } \\
\text { and international legal } \\
\text { practices as the two } \\
\text { primary sources of } \\
\text { international law) }\end{array}$ \\
\hline & - & $\begin{array}{l}\text { In addition, international } \\
\text { legal sources are actually } \\
\text { more in superior } \\
\text { hierarchical sense rather } \\
\text { than national law, so that } \\
\text { international law can be } \\
\text { enforced without the need } \\
\text { to be further transformed. } \\
\text { However, the constitution } \\
\text { of a country can only } \\
\text { provide certain exceptions, } \\
\text { where national courts can } \\
\text { only apply laws produced } \\
\text { from national legislative } \\
\text { bodies. In this case, the } \\
\text { court will only implement } \\
\text { international agreements } \\
\text { after being transformed } \\
\text { into national regulations. }\end{array}$ & $\begin{array}{l}\text { 3. The content of the } \\
\text { regulations (national } \\
\text { law regulates the } \\
\text { running of the state } \\
\text { and relations between } \\
\text { countries-individuals, } \\
\text { while international law } \\
\text { mainly regulates } \\
\text { relations between } \\
\text { countries). } \\
\text { According to this } \\
\text { theory, in order to be } \\
\text { valid in the domestic } \\
\text { sphere, the legal norm } \\
\text { must be transformed } \\
\text { into national law. } \\
\text { Anzilotti: International } \\
\text { rules are only possible } \\
\text { to the extent that they } \\
\text { can rely on national } \\
\text { rules. } \\
\text { Antonio Cassese: }\end{array}$ \\
\hline
\end{tabular}




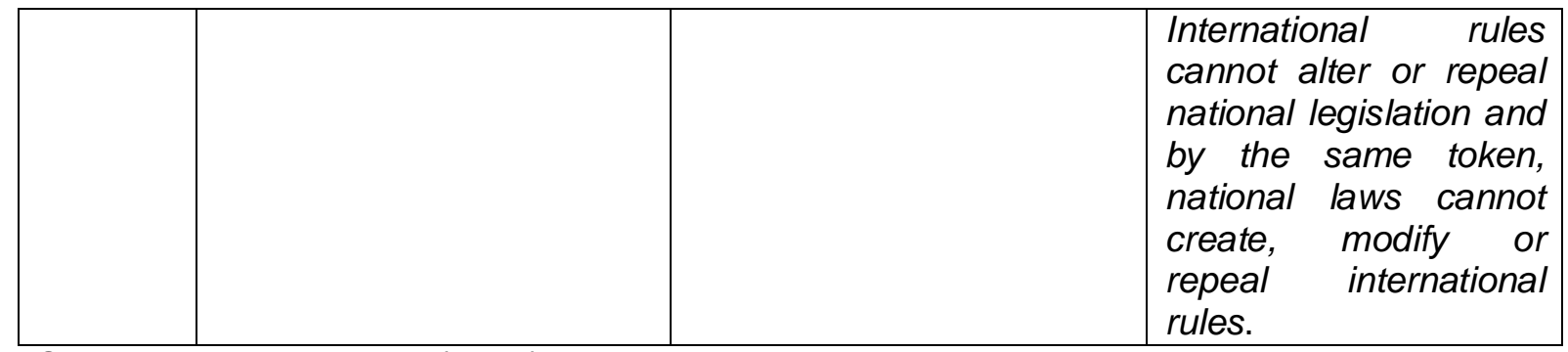

Source: Eddy Pratomo, (2016), Hukum Perjanjian Internasional: Dinamika dan Tinjauan Kritis terhadap Politik Hukum Indonesia, Jakarta: PT. Elex Media Komputindo. pp. 139.

According to Damos Dumoli Agusman, modern legal countries such as the United States, Britain and the Western Europes, the development of the doctrine of legal relations has been rolled out since the beginning of the 20th century through a fairly long process of public discourse including in the legislative process and jurisprudence which eventually crystallized in a choice of legal politics both monism, dualism and a combination of both. In these countries, the issue of international legal position both international customary law and international agreements in their national law has been completed and in general can be mapped as adherents of the monism (Dutch, Italian, French), dualism (United States, United Kingdom, Australia) or a combination of both (German, monism for international customary law and dualism for international agreements). (Agusman, 2010: 98)

Meanwhile, Mochtar Kusumaatmadja stated the position of international law in Indonesian national law is as such: "... We do not adhere to the theory of transformation especially the system of the United States. We are more inclined towards the continental European system of countries ... that is, we immediately consider ourselves bound to the obligation to implement and obey the provisions of agreements and conventions that have been ratified without the need to create a law or act(implementing legislation)."(Kusumaatmadja and Agoes, 2015: 92)

Mochtar Kusumaatmadja in his book Introduction to International Law also states: "... But in some respects the enactment of national laws is absolutely necessary. Certain things in question are when the ratified international agreement contains provisions for the need of changes in national laws that directly concern citizens' rights as individuals. " (Kusumaatmadja and Agoes, 2015: 94)

Responding to Mochtar Kusumaatmadja's opinion, Eddy Pratomo argued that the principle contained in Mochtar's opinion adheres to the principle that leads to the incorporation theory (towards international agreements that state as subject to bounding international law externally) and the transformation theory (towards international agreements where every citizen is internally bound) (Pratomo, 2016: 418)

Related to the previous opinion, Eddy Pratomo stated that Mieke Komar Kantaatmadja also had a similar view, such as the need to transform the Convention into legislation, "If the material of the convention to be applied is different from the existing legal provisions (and has not changed), because it is based on old international conventions while RI has been bound by new conventions ... "(Pratomo, 2016: 418)

In line with the views above, Hikmahanto Juwana, Professor of International Law at the University of Indonesia inferred: "... Every international agreement that has been followed by Indonesia that contains an obligation to be implemented at the national level (whether ratified or 
not) needs to be translated or transformed into national law. So that the international agreements that have been followed won't stop at just the ratification. The Indonesian government has an obligation to comb through various Indonesian laws and regulations and determine which ones are contradictory and which are not regulated where rules need to be made."(Pratomo, 2016: 419)

Eddy Pratomo gave an example of Indonesia's participation in the United Nations Convention Against Corruption (UNCAC), as follows: "For example, Indonesia's participation in UNCAC which is currently being translated into Law No. 31 of 1999 concerning the Eradication of Corruption Crime (PTPK Law) which is in effect will be amended and adjusted to UNCAC. If there are cases that directly use UNCAC, of course that cannot be done because it is impossible for the defendant to be charged with an international agreement. If there are conflicting provisions between UNCAC and the PTPK Law, the PTPK Law applies because the UNCAC is not yet a positive law."(Pratomo, 2016: 419-420)

When paying attention to the views of several international law experts mentioned above, a temporary conclusion can be drawn that the combination theory which are incorporation theory and the transformation theory regarding the position or status of international agreements in Indonesian national law is a practice currently underway in the Indonesian constitutional system. (Pratomo, 2016: 420)

However, Eddy Pratomo added few countries that do not clearly follow one of the ideals (monism and dualism) in their practice of statesmanship, such as Indonesia. Consequently, the status and implementation of international law (including the application of the provisions of international agreements) is unclear(Pratomo, 2016: 137-138). Sefriani (2016: 117-118) emphasized that although the practice of Indonesia does not clearly adhere to a doctrine, and there are diverse opinions from many legal experts on this matter. Some experts stated that without implementing regulations in national law, international laws could not be applied.

Indonesian practice relating to the position of international law (international agreements/convention) in national law, if referring to Law No. 24 of 2000 concerning International Treaties it does not explicitly explain the position of international agreements in the legal system, but only states that international agreements are passed by a Law/PresidentialRegulation without further explaining what their meanings and consequences are for Indonesian legislation. Whether through ratification international agreements are made equivalent to the Law are questions that remain unanswered to date. (Agusman, 2010: 96)

When further studied in Law No. 10 of 2004 which has undergone changes to Law No. 12 of 2011 concerning the Establishment of Legislation Regulations, international agreements are still not included in the composition of the types of legislation. This can be seen in Article 7 regarding the hierarchy of legislation as follows:

Table 3. Comparison of Legislation Hierarchy

\begin{tabular}{|l|l|}
\hline \multicolumn{1}{|c|}{ Law No. $\mathbf{1 0}$ of $\mathbf{2 0 0 4}$} & \multicolumn{1}{c|}{ Law No. 12 of $\mathbf{2 0 1 1}$} \\
\hline $\begin{array}{l}\text { a. The 1945 Constitution of the } \\
\text { Republic of Indonesia; }\end{array}$ & $\begin{array}{l}\text { a. The 1945 Constitution of the } \\
\text { Republic of Indonesia; }\end{array}$ \\
\hline- & $\begin{array}{l}\text { b. Decree of the People's Consultative } \\
\text { Assembly (Tap MPR); }\end{array}$ \\
\hline b. Laws/Government Regulations in & c. Laws/ Government Regulations in \\
\hline
\end{tabular}




\begin{tabular}{|l|l|}
\hline Substitute of Laws; & Substitute of Laws; \\
\hline c. Government Regulations; & d. Government Regulations; \\
\hline d. Presidential Decree; and & e. Presidential Decree; \\
\hline \multirow{2}{*}{ e. Regional Regulations. } & f. Provincial Regulations; and \\
\cline { 2 - 2 } & g. District/Regency Regulations. \\
\hline
\end{tabular}

Based on Table 3, it can be seen that the legislative hierarchy in Law No. 10 of 2004 which was later revised in Law No. 12 of 2011 only shows the return of the Decree of the People's Consultative Assembly (Tap MPR) into the hierarchy and the more detailed division of regional regulations, namely provincial regulations and regency / city district regulations. This fact further proves that the doctrine is still unclear about the legal standing of international agreements in Indonesian law.

In the practical level among the government and Indonesian public opinion various thought lines developed and can be mapped as follows: (1) the mindset that places international agreements that have been ratified (ratified) as part of national law; and (2) the mindset that requires the existence of separate national legislation to implement an approved international agreement. (Agusman, 2010: 96)

If the above explanations are reflected towards this study, it gives an illustration of the process of harmonizing international conventions onprotectionof the rights of migrant workers into legislation, in this case Law No. 18 of 2017 concerning the Protection of Indonesian Migrant Workers.

The mechanisms taken must consider the position of international conventions in Indonesian national law. If referring to the theories that have been put forward, are namely monism and dualism by Damos Dumoli Agusman, Sefriani, Mochtar Kusumaatmadja and Etty R. Agoes. Meanwhile, Eddy Pratomo added specific adoption theory, transformation theory, delegation theory and incorporation theory. Thus, Indonesia still combines the school of thoughts and the theories. In the context of this research, the theory of transformation is an explanation of the process of harmonizing international conventions on protection of the rights of migrant workers with Law No. 18 of 2017 concerning the Protection of Indonesian Migrant Workers.

According to Yuli from the Directorate of Placement and Protection of Foreign Workers, Director General of Binapenta and PKK, Ministry of Manpower of the Republic of Indonesia in an interview with researchers regarding the harmonization of international conventions on the protection of migrant workers' rights previously regulated in Law No. 39 of 2004 and stated that: "The harmonized law adapts to the contents of the convention. Where the convention is the basis of national regulation. The convention must be an act of ratification harmonized with Law No. 39 of 2004." (Results of Authors Interview with the Directorate of PPTKLN, Indonesian Ministry of Manpower, January 2017)

The opinion above explains that the international convention, in this study, which is the International Convention on the Protection of the Rights of All Migrant Workerscan be used as a reference after the convention was approved through ratification of the Law as required by Law No. 24 of 2000 concerning International Agreements. The conventions and laws on ratification of the convention have no differences, only translate conventions into Indonesian and provide explanations if there are points that are not agreed upon from the process of ratification. After 
that, the convention can only be harmonized with the relevant law in Indonesian national law, in this study namely Law No. 18 of 2017 concerning the Protection of Indonesian Migrant Workers.

According to the provisions of article 2 paragraph 1 letter a of the 1969 Vienna Convention, international agreements are explained as such: Treaty means an international agreement concluded between states in writer form and governed by international law, whether embodied in a single instrument or in two or more related instrument and whatever its particular designation.WhereasAgusman (2010: 20) states that the definitions of the 1969 and 1986 Vienna Conventions have been adopted by Law No. 24 of 2000 concerning the International Agreement with slight modifications, for example: "every agreement in the field of public law, which is governed by international law and made by the Government with the State, international organizations or other international legal subjects."

In the context of this study, international conventions on the protection of migrant workers' rights have met international criteria (1969 Vienna Convention) and national (Law No. 24 of 2000) as international agreements (conventions). This confirms that this international convention should be a reference for Indonesia to develop a system for protecting Indonesian migrant workers in Law No. 18 of 2017.

One of the sources of Indonesian state law is the international agreement. According to Sirajuddin and Winardi (2015:19), international agreements play a very important role in regulating life and interaction between countries in the international community today. Through international agreements, each country outlines the basis of their cooperation, arranges various activities, and resolves various problems for the survival of the community itself. In a mutually marked world of interdependence today, no country has no agreement with other parties and no country is not governed by agreements in its international life.

After the explanations above, Ni'matul Huda in Sirajuddin and Winardi (2015: 20) stated that the international agreement which later became the source of constitutional law is an international agreement held by Indonesia and other countries, where Indonesia as a sovereign State has bound self to accept the rights and obligations arising from the agreement held, where International agreements are an important source of law. For this reason, there is not enough agreement or treaty signed by Indonesia, but it must also be ratified (obtain approval) before the agreement is binding. In addition to the treaty, there is an ordinary international agreement held by the government or the executive body (executive agreement) with another government that does not require approval (ratification).

Based on the explanation of the theoretical framework, the conceptual framework in this study is presented as follows: Legal harmonization in this research is interpreted as an effort to harmonize international conventions on the protection of the rights of migrant workers that have been ratified in Law No. 6 of 2012 concerning ratification of the International Convention on the Protection of the Rights of All Migrant Workers and Members of their Familieswith the Law No. 18 of 2017 concerning the Protection of Indonesian Migrant Workers. The International Convention on the Protection of the Rights of All Migrant Workers is one of the international instruments that govern the affairs of migrant workers comprehensively. So that the values contained in the Convention can be harmonized into Indonesian national law in the field of employment, especially in the field of labor migration. 
Based on international (1969 Vienna Convention) and national (Law No. 24 of 2000)criteria, international conventions to protect the rights of migrant workers fall into the category of international agreements (conventions). This confirms that this international convention should be a reference for Indonesia to develop a system for protecting Indonesian migrant workers in Law No. 18 of 2017 concerning the Protection of Indonesian Migrant Workers.

\section{B. Development of Harmonization of the International Convention on the Protection of the Rights of All Migrant Workerswith Law No. 18 of 2017 concerning the Protection of Indonesian Migrant Workers}

Furthermore, harmonization of law can be interpreted as an effort or process of adjusting principles and legal systems, in order to realize legal simplicity, legal certainty and justice. Harmonization of law as a process in the formation of laws and regulations, resolving things that are contradictory and irregularities between legal norms in legislation, thus the national legislation is formed in line with the objectives of law, such as justice, expediency and legal certainty (Tanya, 2001: 129-130).

In the context of this research, harmonization of law is interpreted as an effort to harmonize the international conventions to protect the rights of migrant workers that have been ratified in Law No. 6 of 2012 concerning the ratification of the International Convention on the Protection of The Rights Of All Migrant Workers and Members of Their Familieswith the Law No. 18 of 2017 concerning the Protection of Indonesian Migrant Workers. The International Convention on the Protection of the Rights of All Migrant Workers is one of the international instruments that govern the affairs of migrant workers comprehensively. So that the values contained in the convention can be harmonized into Indonesian national law in the field of labor, especially in the field of labor migration.

The mechanismstaken must consider the position of international conventions in Indonesian national law. If referring to the theories that have been put forward, are namely monism and dualism by Damos Dumoli Agusman, Sefriani, Mochtar Kusumaatmadja and Etty R. Agoes. Meanwhile, Eddy Pratomo added specific adoption theory, transformation theory, delegation theory and incorporation theory. Thus, Indonesia still combines the school of thoughts and the theories. In the context of this research, the theory of transformation is an explanation of the process of harmonizing international conventions on protection of the rights of migrant workers with Law No. 18 of 2017 concerning the Protection of Indonesian Migrant Workers.

The opinion above explains that the international convention, in this study, which is the International Convention on the Protection of the Rights of All Migrant Workers can be used as a reference after the convention was approved through ratification of the Law as required by Law No. 24 of 2000 concerning International Agreements. The conventions and laws on ratification of the convention have no differences, only translate conventions into Indonesian and provide explanations if there are points that are not agreed upon from the process of ratification. After that, the convention can only be harmonized with the relevant law in Indonesian national law, in this study namely Law No. 18 of 2017 concerning the Protection of Indonesian Migrant Workers. In addition, this transformation process is needed to adopt the 
substance of the conventions into such regulations because this convention, in essence, has direct consequences towards foreign workers than the Indonesian Migrant Workers.

Judging from the historical view of the harmonization of the International Convention on the Protection of Migrants and Members of Their Families adopted in national law previously regulated in Law No. 39 of 2004 concerning the Placement and Protection of Indonesian Workers Abroad that are still oriented towards placement arrangements compared to the protection and concept of protection of Indonesian Migrant Workers that have not been clearly and explicitly described, then the role of local governments is not optimal and is notmandated derivative regulations to provide protection for Indonesian Migrant Workers by the local governments, thus the obligations to protect IMW are more charged to PPTKIS (Placement Companies/Private), and then the institutional arrangements between the Ministry in charge of Manpower and the Agency formed specifically to manage the placement and protection of migrant workers are still not synergistic.

In addition, evaluation was also carried out by identifying the contents of articles and paragraphs in Law No. 39 of 2004 from The Institute for Ecosoc Rights in collaboration with the Tifa Foundation as cited in the Academic Draft of the PPILN Bill in outline is as follows. The articles and paragraphs evaluated were identified by five clusters of analysis, including: (1) provisions or contents that did not protect or actually harm IMW, (2) unclear provisions or content, vague in its meanings and implications, (3) incomplete provisions or contents, (4) contradictory and inconsistent provisions or content, and (5) provisions or contents that cause institutional conflict.

The first cluster highlighted the practice of change and the creation of work agreements submitted to PPTKIS which were worried to have an interest in benefiting from the process, even though the role of the state through Indonesian representatives was needed by IMW. The second cluster divides the unclear articles into three criteria, that is the articles that mandate a further stipulation such as the articles explaining that the problems revealed in a particular article will be further arranged or reestablished by other regulations or decisions of certain high officials, the meaning of the relevant agencies that blurred and government instransparency as in the management of the government to mediate between problematic migrant workers and the inability of PPTKIS to provide compensation.

The third cluster focuses on articles that are not intact and unclear so that they can lead to diverse and easily perverted interpretations, exemplified in the articles related to work agreements that have many problems and limited involvement of parties involving only PPTKIS and the government, other examples is data collection of prospective IMW is not equipped with important documents such as Family Cards to prevent unauthorized recruitment.

The fourth cluster highlighted articles that showed inconsistencies and contradicted the articles itself, such as the article which authorizes PPTKIS to provide protection, while in another article it was stated that the government was responsible for the entire placement process from departing to returning to the homeland. The delegation of responsibility from the government to the private sector raises the problem of neglecting the protection of migrant workers because the interests of PPTKIS are to get the maximum benefit from the business being run. So that the responsibility for the protection of migrant workers must be returned to the 
government so that it is carried out effectively and coordinated. Other inconsistent articles related to the duties, responsibilities and obligations of the government that states the government is tasked with regulating, fostering, implementing and supervising. These tasks certainly cannot be carried out by one party only, so that the duties and responsibilities need to be specified to avoid overlapping, such as: the minister as policy maker, supervisor and supervisor and BNP2TKI as the executor of operational policies.

The fifth cluster emphasizes the articles that give rise to institutional conflict, such as the article which mandates the establishment of BNP2TKI, but on the other hand this Law is a product of government policy that is under the authority of the Minister in charge of Manpower. This law does not specifically explain the relationship between BNP2TKI and the Ministry of Manpower, whether each of them stands separately or both are required to cooperate. As a result, the implementation of this Law still does not show the synergy and coordination of work between the two institutions which are the shelter for Indonesian Migrant Workers.

From the results of interviews with the representative of the Indonesian Ministry of Manpower it can be understood that Law No. 39 of 2004 has undergone a process towards change that has been included in the national legislation program (prolegnas). The international conventions that have been approved through the ratification process, although the content has been considered good (in mainstreaming the protection of migrant workers) but still needs to be adapted to the conditions and needs of Indonesia. So that the goal of providing protection for all Indonesian workers abroad can be felt in a complete (comprehensive) manner at each stage of the placement (universal).

In addition, the results of interviews with speakers from BNP2TKI also provided an illustration that in the perspective of the implementers of the placement and protection of migrant workers who were given the mandate by the Law, they still found obstacles in the implementation of Law No. 39 of 2004. First, concerning the application of the Law towards professional Indonesian Migrant Workers, this should be noted considering that at the end of 2015 Indonesia had officially entered the era of the ASEAN Community, thus the arrangements of Indonesian Migrant Workers should also be directed to the placement of professional IMW in the Southeast Asian region and countries in need. Second, the proportion of IMW placements that are still dominated by domestic helpers (PLRT) or domestic servants (PRT) at the time of drafting Law No. 39 In 2004 until now it needs to be recalculated, because the trend of IMW placement has shifted from informal IMW with the largest proportion, to being balanced with the demand for IMWs in the formal sector. Third, inter-agency coordination needs to be increased to avoid obscurity/overlaps regarding their respective duties, authorities and responsibilities. Fourth, relating to the blank mandate in the Law needs to be considered so that it is reduced to the Law that will be amended.

In the last stage, the government finally passed the united law which regulates Indonesian workers who work abroad by changing Law No. 39 of 2004 concerning the Placement and Protection of Indonesian Overseas Workers into Law No. 18 of 2017 concerning the Protection of Indonesian Migrant Workers, in this latest regulation no longer found the term Indonesian Workers' Association (TKI), but Indonesian Migrant Workers (PMI). Law No. 6 of 2012 concerning the Ratification of the Internasiional Convention on the Protection of the Rights 
of All Migrant Workers and Members of Their Families is a preamble considering the Law No. 18 of 2017 concerning the Protection of Indonesian Migrant Workers. The consequences of these considerations according to Maria Farida are the main points which contain philosophical, juridical, and sociological elements which are the background for making the law. (Maria Farida, 2007: 108). Based on this legal fact, it can be concluded that the latest development of the harmonization of international conventions on the protection of migrant workers in the national legal system has been contained in Law No. 18 of 2017 concerning the Protection of Indonesian Migrant Workers.

\section{Adoption of the Substance of the International Convention on the Protection of Migrant Workers' Rights into Law No. 18 of 2017 concerning the Protection of Indonesian Migrant Workers}

The International Convention on the Protection of the Rights of All Migrant Workers is one of the laws and regulations relating to the placement and protection of Indonesian migrant workers originating from the laws resulting from ratification. The Convention has been ratified through Law No. 6 of 2012. The technical explanation regarding the harmonization of the International Convention with the Act has been explained in the previous section. In this section, the researcher will focus on the substance of the convention adopted into Law No. 18 of 2017 concerning the Protection of Indonesian Migrant Workers.

The results of the analysis show that there are 7 findings in Law No.18 of 2017 which have adopted the substance of the convention. The first finding was the definition of migrant workers who fully adopted the definition of the Convention into the Amendment Bill. The second finding concerns the limitation of the scope of the application of the Law which adopts the limitations of the scope of the provisions of the Convention. The third finding concerns the definition of "Family", although it does not fully adopt the definition of the Convention but the substance of the definition has been included in the provisions of the Convention. The fourth finding concerning the principle of protection of Indonesian migrant workers adopts the values of the Convention, especially the principle of equality of rights and principles of anti-discrimination, as well as the principle of protection of privacy. The rest is related to related regulations originating from national law.

Furthermore, the fifth finding regarding the authority of the government is to close access to the destination country with consideration of security and protection in accordance with the acquisition of the convention to limit IMW's right to free entry in accordance with the laws/regulation of the country of origin. The sixth finding regarding the protection of the rights of Indonesian migrant workers and their families related to the Convention and the Amendment Bill includes: the right to worship, the right to access communication, the right to receive all the property of Indonesian migrant workers who die abroad and the right to know their rights and obligations of migrant workers. The seventh finding was regarding the obligation of the Indonesian government to provide protection for migrant workers in the country of placement through representation. However, troubled migrant workers remain accountable for their criminal and/or civil matters personally. 
In general, Law No. 18 of 2017 on the Protection of Indonesian Migrant Workers has adopted the substance of the Convention (Law No. 6 of 2012), both through written adoption and value adoption as described in the previous explanation.

The process of adopting the substance of International Convention on the Protection of the Rights of All Migrant Workers went through two processes, that is the political process and legal process. The political process has been taking place since the office term of the House of Representatives of the Republic of Indonesia for the period 2009-2014 and included in the National Legislation Program (Prolegnas), but was not completed in that period. The process was continued during the period of service of the House of Representatives of the Republic of Indonesia on 2009-2014 which was also included in the National Legislation Program. The statement which implies that the harmonization of the Convention (Law No. 6 of 2012) will only be stated and documented in the Meeting between Commission IX and the Government on January 19, 2016. In addition, the efforts of civil society organizations were also carried out through actions and discussions that demanded the government to adopt the Convention into Law.

Legal processes are also carried out to adopt the substance of the convention as described above. The researcher found the substance of the convention began to appear in the academic text of the Indonesian Overseas Workers Protection Bill 7 June 2012 version. In addition, the demand for adopting the substance of the Convention was also carried out by the Indonesian Association for Migrant Care Workers through 16 points of change based on principles of the ILO Convention and the Migrant Workers Convention. The government also drafted the main points of the Draft Bill on Law No. 39 of 2004 to become Law No.18 of 2017, but does not specify the substance adopted from the Convention, but focuses more on structuring the authorized Ministries/Institutions. Researcher found in general the changes to Law No. 39 of 2004 into Law No. 18 of 2017 has adopted the substance of the Convention through written adoption and adoption of values. Written adoption identified 7 findings, while the adoption of values was identified through the context of protection and involvement of family members in the substance of the Law, as well as references to international customary law in providing protection for Indonesian migrant workers.

\section{Conclusion and Recommendation}

\section{A. Conclusion}

Harmonization of the international convention to protect the rights of migrant workers with Law No. 39 of 2004 carried out through a transformation process that refers to the position of international conventions in Indonesian national law. Law No. 39 of 2004 experienced disharmony due to the orientation of the law still in the placement arranging compared to protection. Thus in the last phase of the development of harmonization the International Convention on the Protection of The Rights of All Migrant Workers and Members of Their Familiesis standardized through Law No. 18 of 2017 for Protection of Indonesian Migrant Workers.

The substance of the international convention on the protection of migrant workers' rights was adopted through two processes, the political process through the discussion of the Amendment Bill on Law No. 39 of 2004 in the House of Representatives of the Republic of 
Indonesia which currently has become Law No. 18 of 2017 Protection of Indonesian Migrant Workers and the involvement of civil society organizations and legal processes by referring to Law No. 6 of 2012 in the Draft Law Amendment to Law No. 39 of 2004 version of May 2016 and identified 7 findings comparing the Amendment Bill and the ratification of the Convention. As well as the context of the protection and involvement of family members who have been harmonized in the substance of the Act.

\section{B. Recommendation}

This study found that the position of international law is still blurred in the Indonesian legal system, especially in the constitutional law system, thus the author recommends the Ministry of Foreign Affairs, Republic of Indonesia and Ministry of Law and Human Rights, Republic of Indonesia as Executive representatives and the House of Representatives (DPR) as Legislative representatives along with related parties to discuss more comprehensively and intensively about the position of international law in Indonesian legal system by considering all its implications for the criminal, civil, business and state administration system. Furthermore, academicians are expected to be able to conduct interdisciplinary and multidisciplinary academic studies to reveal the other side of the relationship between international law and the national law in Indonesia.

\section{References}

Ardiani, Natasha Karina. 2009. Ratification of UN Convention on Migrant Workers (1990): The Case of Indonesia and The Philippines. Indonesian Journal of Social Sciences Vol. 1 No. 3 2009.

Baharuddin, Hamza and Achmad Zulfikar. 2017. Status of International Law in Indonesian National Law: Review of International Conventios in Indonesian Legal System. Proceeding of 2nd International Research Conference on Economics, Business and Social Sciences.

Agusman, Damos Dumoli. 2010. Hukum Perjanjian Internasional: Kajian Teori dan Praktik Indonesia. Bandung: Refika Aditama.

Iskandar, Pranoto (ed.) .2011. Standar Internasional Migrasi Ketenagakerjaan Berbasis HAM. Cianjur: IMR Press.

Farida, Maria, I. 2007. Ilmu Perundang-Undangan Proses dan Teknik Pembentukannya. Yogyakarta: PT. Kanisius.

Fajar ND, Mukti dan Yulianto Achmad. 2010. Dualisme Penelitian Hukum Normatif \& Empiris. Yogyakarta: Pustaka Pelajar.

Kusumaatmadja, Mochtar dan Etty R. Agoes. 2015. Pengantar Hukum Internasional. Bandung: Pusat Studi Wawasan Nusantara, Hukum dan Pembangunan dan PT. Alumni. 
Naskah Akademik Rancangan Undang-Undang Perlindungan Pekerja Indonesia di Luar Negeri (RUU PPILN), $27 \quad$ Mei 2015.2 Diunduh dari: http://wikidpr.org/uploads/ruu/56a7b0390d00db504b000027/naskah-akademik-ruuperlindungan-tenaga-kerja-di-luar-negeri-27-mei-2015.pdf, tanggal 3 Juni 2017.

Pratomo, Eddy. 2016. Hukum Perjanjian Internasional: Dinamika dan Tinjauan Kritis terhadap Politik Hukum Indonesia, Jakarta: PT. Elex Media Komputindo.

Putra, Akbar Kurnia. 2015. Harmonisasi Konvensi Cyber Crime dalam Hukum Nasional. Jurnal Ilmu Hukum Vol. 5 No. 2 Tahun 2014. p. 95-109.

Sampara, Said dan La Ode Husen. 2016. Metode Penelitian Hukum Edisi Revisi. Makassar: Kretakupa Print.

Situmorang, Mosgan. 2014. Harmonisasi Hukum Nasional di Bidang Korupsi dengan United Nations Convention Against Corruption. Jurnal RechtsVinding: Media Pembinaan Hukum Nasional Vol. 3 No. 3 Desember 2014. p. 329-346.

Sirajuddin dan Winardi. 2015. Dasar-Dasar Hukum Tata Negara Indonesia. Malang: Setara Press.

Sefriani. 2016. Peran Hukum Internasional dalam Hubungan Internasional Kontemporer. Jakarta: Rajagrafindo Persada.

Tanya, Benard L. 2010. Teori Hukum, Strategi Tertib Manusia Lintas Ruang dan Generasi, Yogyakarta, Genta Publishing.

Zulfikar, Achmad. 2014. Indonesian Migrant Workers Protection Abroad: Indonesian Law PostRatification of International Convention on Migrant Workers. Juris Gentium Law Review Vol. 2 No. 1 September 2014. p 30-41

Zulfikar, Achmad. 2015. Rasionalitas Ekonomi Politik dalam Ratifikasi Konvensi Internasional Perlindungan Hak Pekerja Migran Tahun 2012. The Politics: Jurnal Magister IImu Politik Universitas Hasanuddin 1 (1) 2015. pp. 37-49.

Zulfikar, Achmad. 2017. Harmonisasi Konvensi Internasional Perlindungan Hak Pekerja Migran dengan Undang-Undang Nomor 39 Tahun 2004. Tesis. Universitas Muslim Indonesia. 